ZAPISKi HistoryCZNE t. 85, 2020, z. 4, s. 89-110

ISSN 0044-1791

http://dx.doi.org/10.15762/ZH.2020.36

WOJCIECH MATERSKI*

(iD https://orcid.org/0000-0002-2040-362X

\title{
The Problem of the Demarcation of the Border BETWEEN ESTONIA AND Russia IN 1917-1920
}

\begin{abstract}
The article addresses an important but little-known issue of the conflict over the demarcation of the border between Estonia and (Soviet) Russia in the years 1917-1920, which was important for the international order in North-Eastern Europe after the First World War. The dispute over this matter was much broader than just bilateral, as the normalization of the situation in the Baltic region conditioned the possibility of extending the international order established by the Treaty of Versailles to Eastern Europe. This issue has not received a separate monograph so far, although it was addressed in historical publications, especially in the countries directly concerned. The analysis of the state of research, confronted with primary sources, constitutes the base for the article. After the Bolshevik Revolution of 1917, Estonia quickly became an object of interest for the Bolsheviks, which almost ended up with the republic losing its independence. However, the politicians of the newly born Republic of Estonia showed great political skills by manoeuvring between Germany, the White and Red Armies, obtaining British aid and establishing military cooperation with Latvia, which was equally threatened. However, it was the Polish-Soviet War, which ended with the defeat of the Red Army, that turned out to be crucial. During disputes with the Whites and the Bolsheviks with regard to demarcation, Estonia successfully, at least in a shortterm perspective, defended its historical rights to the regions of Narva and Petseri against its aggressive neighbour. From the point of view of diplomatic possibilities, the Estonians achieved everything that was achievable. The peace treaty signed in Tartu in 1920 ensured 'perpetual guarantees' which, however, lasted only for less than two decades.
\end{abstract}

Keywords: Republic of Estonia; the fall of the Russian Empire; Bolshevik Revolution; demarcation; conflicts over borders; peace treaties; right of peoples to self-determination

\footnotetext{
* Institute of Political Studies, Polish Academy of Sciences,

@wmat@isppan.waw.pl
} 
Historically, the lands of modern Estonia and Finland constituted an ethnic Finno-Ugric unity, as this region was almost entirely inhabited by the Finno-Ugric peoples. The undefined border between them and the Slavic settlement areas ran along the Kunda River (today's province of West Virumaa). Over time, the region became diversified under the dominant influences of the Swedes in Finland and the Germans in Estonia which emerged in the medieval period ${ }^{1}$. This region bordering Novgorod the Great on the east ${ }^{2}$, was controlled by the Order of Livonian Brothers of the Sword (Latin Fratres militiae Christi de Livonia), and later, after it had been incorporated into the State of the Teutonic Order (1237), by the Livonian Order, that is, the Livonian branch of the Teutonic Order (German Brüder der Ritterschaft Christi von Livland). In the late sixteenth century, these lands were divided between the Polish-Lithuanian Commonwealth, Kingdom of Sweden and Kingdom of Denmark ${ }^{3}$.

The lands inhabited by the Estonians were unified in the mid-seventeenth century by Christina, Queen of Sweden. Soon, however, as a result of the Great Northern War (1700-1721), the entire Estonian region with the population of about 350,000 inhabitants was annexed by the Russian Empire. Partly as the Governorate of Estonia (Estland) with its capital in Reval, and partly as part of the Governorate of Livonia (Lifland) with its capital in Riga. In a Russian atlas published in 1792, the border of both these governorates with the Governorate of St Petersburg ran from the Narva Bay along the Narva River (Estonian Narva, Russian Narwa alias Narowa) to the western shores of Lake Peipus (Estonian Peipsi järv, Russian Chudskoye) and Lake Pskovskoye (Estonian Pihkva järv), to the mouth of the Varska River (Estonian Värska) and further south between the villages Kachkowa (Estonian Kahkva) and Trojena (Estonian Tresna) to the town Lucyn (Latvian Ludza) ${ }^{4}$. The administrative imposition of

\footnotetext{
${ }^{1}$ Jan LEWANDowski, Estonia, Warszawa 2001, pp. 13-14. For more, see Глеб С. ЛеБедЕВ, Этногенетические процессы и образование государств в Восточной Европе (балты, финно-угры, славяние), [in:] Проблемы этногенетических исследований Европейского Северо-Востока, Сыктывкар 1982 [Gleb S. Lebiediew, Etnogeneticheskiye protsesy i obrazovaniye gosudarstv $v$ Vostochnoy Yevrope (balty, finno-ugry, slavyaniye), [in:] Problemy etnogeneticheskikh issledovaniy Yevropeyskogo Severo-Vostoka, Syktyvkar 1982], passim.

${ }^{2}$ It existed as an independent state (the Novgorod Republic) from the twelfth century. In 1478, it was conquered by Ivan III the Great and incorporated into the Grand Duchy of Moscow.

${ }^{3}$ Эдгар Маттисен, Эстония-Россия. История границы и её проблемы, Та́ллинн 1995 [Edgar Mattisen, Estoniya-Rossiya. Istoriya granitsy i yeyë problemy, Tallinn 1995], pp. 17-20; Bohdan CYwiŃski, Szańce kultur. Szkice z dziejów narodów Europy Wschodniej, Warszawa 2013, pp. 320-331.

${ }^{4}$ Российский атлас из сорока четырёх карт состоящий и на сорок два наместничества империю разделяющий, сост. Александр М. ВилььРехт, Москва 2006 [Rossiyskiy atlas $i z$ soroka chetyrëkch kart sostoyahchiy i na sorok dva namestnichestva imperiyu razdelyayushchiy, sost. Aleksandr M. WiLbRECHT, Moskva 2006]. Such a demarcation continued essentially until
} 
the governorate's borders at that time, partly against historical traditions and ethnic divisions, gave rise to territorial disputes between Estonia and (Soviet) Russia, and to a smaller extent between Estonia and Latvia, although the Governorate of Estonia at that time was ethnically almost homogenous ${ }^{5}$. Its importance to the Russian Empire was determined primarily by the Baltic ports, which, at the time when the Gulf of Finland was frozen (four to five months a year), took over the maritime trade of St Petersburg. Until the outbreak of the First World War, Reval (from 1918 officially named Tallinn) had been a significant shipbuilding hub, a base for the stationing of Russian navy, and the main naval base of Russian cruisers and minelayers.

The dispute over demarcation introduced in the title of this article essentially boils down to two small territories: 1.2 thousand $\mathrm{km}^{2}$ on the eastern bank of the Narva River and 1.1 thousand $\mathrm{km}^{2}$ of the Petseri County (Estonian Petserimaa alias Setumaa, Russian Petchori).

The area on the eastern bank of the Narva River called Ingria (Estonian Ingeri alias Ingerimaa) bounded by the Gulf of Finland, Lake Peipus and the Neva River, although sparsely populated ${ }^{6}$, played an important strategic role. Having control over this area meant controlling trade, maritime and inland transport, and blocking or opening Russia's passage to the Baltic Sea. At the end of the fifteenth century, Tsar Ivan III the Great erected the Ivangorod Fortress (Estonian Jaanilinn) on the eastern bank of the Narva River, as a counterbalance to the Narva Fortress (Estonian Narva) on its western bank. After the Great Northern War, the Narva River lost its function as a border, as the lands on both its banks became part of one governorate of the Russian Empire $^{7}$, the most important consequence of which was a gradual Russification

the First World War, see Karte von Ehstland: mit den Kreis-, Polizeidistricts- und Guts-Grenzen so wie den Plänen der Städte, bearb. v. Johann H. SснмidT, Reval 1884.

${ }^{5}$ According to the 1897 census of the Russian Empire, the governorate was inhabited in 91\% by Estonians (Finno-Ugric people), $4 \%$ by Germans and $4 \%$ by Russians. The governorate consisted of four administrative units: Harjumaa with its centre in Reval (Estonian Tallinn), Virumaa with its centre in Wesenberg (Estonian Rakvere), Järvamaa with its centre in Weissenstein (Estonian Paide), and Läänemaa with the island of Dagö and with the centre in Hapsal (Estonian Haapsalu). Seе Первая всеобщая перепись населения Российской империи. 1897, Т. 49: Эстландская губерния, ред. Николай А. Тройницкий, Владимир В. НиєудАчин, Санкт-Петербург 1905 [Pervaya vseobshchaya perepis' naseleniya Rossiyskoy imperii. 1897, t. 49: Estlandskaya guberniya, red. Nikołaj A. TrojNickiJ, Władimir W. Nieudaczin, Sankt Peterburg 1905].

${ }^{6}$ These areas, from both banks of the Narva River to Lake Ladoga, were inhabited by FinnoUgric tribes collectively referred to as the Maaväki (the Izhorians, Votians, Ingrian Finns and other minor ones).

${ }^{7}$ Initially, the Governorate of Ingermanland (Ingria), established in 1703 after Ingria had been obtained from the Kingdom of Sweden, in 1710 transformed into the Governorate of St Petersburg - in connection with the city's expansion, and then the Governorate of Reval alias Estland (from 1719). 
of the population and their conversion to Orthodox Christianity. From then on, both cities, Narva and Ivangorod, were treated as one twin city until 1944.

The fate of the Petseri County, separated from the Narva River by Lake Peipus, constituted a geographical unity with the Latvian Abrene County, which was its extension (in 1925-1938 officially named Jaunlatgale and after 1945 named Pytalovo), was similar. It was inhabited by the Seto people (Setus, Setu), ethnically closest to the Estonians. The border formed in the thirteenth century along the Maidla River (Estonian Maidla jõgi) and the upper Piusa River (Estonian Pimža jõgi), which separated the lands under the rule of Novgorod the Great from the areas subjugated to the Germans, left the Petseri County under the control of the former. Over time, it became a religious border, as the population of the region adopted Orthodox Christianity, the local centre of which became the Petseri Monastery founded in the fifteenth century8. Whereas the population of the lands to the west of it was Catholic and, subsequently, converted to Lutheranism. The confessional division was maintained after the Russian Empire took over these lands, despite the fact that they were merged into one administrative unit, that is the Governorate of Pskov ${ }^{9}$ established in 1772. It is still noticeable today.

After the outbreak of the First World War, German troops occupied the Governorate of Courland (western Latvia) and part of Lithuania, which made the Estonian lands a supply base for the military front for a long time. Russian army garrisons (ground forces) stationed in all larger cities, the number of which exceeded 100,000 armed soldiers at the beginning of $1917^{10}$. This military 'saturation' had a negative impact on the Estonian lands similar to that on other war-ridden lands of the Russian Empire. It also resulted in the emergence of movements for autonomy and independence, however, weaker than, for example, in the nearby Grand Duchy of Finland ${ }^{11}$.

After the February Revolution in Russia, on 26 March (8 April), Estonian politicians sent a manifesto to Georgy Lvov, Prime Minister of the Interim Government, with a proposal to grant Estonia autonomy, including a project to reorganise the local government in Estland and the Estonian part of Lifland ${ }^{12}$.

${ }^{8}$ It is also known as the Pskov-Pechory Lavra, one of the five lavras (a large male monastery) in the Russian Empire.

${ }^{9}$ Previously, part of the Governorate of Ingermanland (Ingria), then the Governorate of Pskov (1708-1717), the Governorate of Novgorod (1727-1772). In the years 1777-1796, the governorate was called the Pskov Viceroyalty. The territory was also called 'Pskov Ruthenia'.

${ }^{10}$ Мати ГРАФ, Эстония и Россия 1917-1991. Анатомия расставания, Та́ллинн 2007 [Mati Graf, Estoniya i Rossiya 1917-1991. Anatomiya rasstavaniya, Tallinn 2007], pp. 22-23.

${ }^{11}$ Cf. Wojciech MatersKi, Od „eksportu rewolucji” do "finlandyzacji”. Sowiecko-fiński spór terytorialny 1917-1991, Warszawa 2019, pp. 15-17.

${ }^{12}$ The project was prepared by Estonian social activists from Tallinn and Tartu, see Алекса́ндра Ю. БАХтү́ринА, Изменение административных грании Прибалтийских губерний 
As early as on 30 March (12 April) 1917 the Interim Government adopted a regulation titled 'On the Autonomy of Estland', which was probably related to the very good rapport between the leaders of the Estonian national movement and the ministers of Prince Lvov's cabinet ${ }^{13}$. New lands dominated by the Estonian people were incorporated into the Governorate of Estonia: the provinces (counties) of Võru (Estonian Võru maakond), Pärnu (Estonian Pärnu kreis), Kuressaare (Estonian Kuressaare kreis), Fellin (Estonian Fellinsche kreis) and Dorpat (Estonian Tartu kreis), as well as part of Valga County (Estonian Valga kreis). At the same time, it was given a new name - the Autonomous Governorate of Estonia (Estonian Esti autonoomne kubermang). In May, the government issued a directive which contained, among other things, rules for the demarcation of the Estonian and Latvian territories, which was to be carried out by an arbitration committee made up of the representatives of the governorates of Estland and Lifland ${ }^{14}$.

The liberalisation resulting from the February Revolution encouraged the political maturity of society, and thus the formation of native political parties. They formed political competition for the local branches of Russian parties: Cadets, Mensheviks, Social Revolutionaries and Bolsheviks, which had been active on the Estonian territory until then. A number of regional parties, as well as parties related to particular business sectors, which were similar to trade unions, were also formed. Generally speaking, it was Estonian Bolsheviks and nationalists, who gradually gained increasingly more support among the delegates of Estonia regional councils. They were mainly centred around the representation of local political and social organisations that played the role of the Interim Parliament (Estonian Maapäev).

However, in the left-wing-dominated delegate councils, the issue of borders (territorial divisions) was marginal. It was social issues - a class rather

весной-летом 1917 г., Вестник Российского Гуманитарного Государственного Университета. Политология. История. Международные отношения, № 4/2: 2017 [Alexandra Ju. BAKHTURINA, Izmienienije administratiwnych granic pribałtijskich gubierni wiesnoj-letom $1917 \mathrm{~g}$., Vestnik Rossiyskogo Gumanitarnogo Gosudarstvennogo Universiteta. Politologiya. Istoriya. Mezhdunarodnyye otnosheniya, no. 4/2: 2017], p. 179.

${ }_{13}$ These good relations resulted from their work together in the IV State Duma, see Kapстен БРюГгемАнн, Эстония и Петроградский фронт гражданской войны в 1918-1920 г2., Вопросы истории, 2007, № 5 [Karsten BRÜGgemanN, Estoniya i Petrogradskiy front grazhanskoy voyny v 1918-1920 gg., Voprosy istorii, 2007, no. 5], p. 19; Сергей А. КОчЕГАРОВ, Военнополитические аспекты становления независимого эстонского госудаства (1917-1920 годы), Санкт-Петербург 2018 [Siergiej A. Koczegarow, Voyenno-politicheskiye aspekty stanovleniya nezavisimogo estonskogo gosudarstva (1917-1920 gody), Sankt Peterburg 2018], p. 13.

${ }^{14}$ Ultimately, this demarcation was not carried out, see A. Ju. BAKHTURINA, op.cit., pp. 179-180. For more, see Tomasz PAluszyński, Walka o niepodległość Estonii 1914-1920, Poznań 2007. 
than national approach - that dominated ${ }^{15}$. Nationalists, on the other hand, essentially reduced their activity to repeating the slogan of autonomy, occasionally voicing a general need to unite historical territories ${ }^{16}$.

A combination of external circumstances created the opportunity for an independent Estonian state to emerge at the end of the First World War, despite the obvious weakness of the local elites, which, at most, aspired to autonomy within the Russian state almost to the very moment that the independence was gained ${ }^{17}$. Thanks to the Estonian autonomists, who had their lobbies in Petrograd, on 9 (22) June, the Interim Government approved the Rules of Procedure on the 'Interim Organisation of Managing the Administration and the Self-Government of the Governorate of Estland'. This legal act, with reference to the regulation of $30 \mathrm{March}$, confirmed that the Governorate of Estland incorporated the northern counties of the Governorate of Lifland inhabited mostly by the Estonians, that is the counties of Kuressaare, Fellin, Dorpat, Pärnu, and Võru, as well as part of the Valaga County inhabited by the Estonians. It announced the creation of an advisory body at the office of the governorate commissar - the Interim Land Council of the Governorate of Estland ${ }^{18}$.

The new regulation did not take into account the national specificity of the Petseri County, densely populated by the Seto people. In September, this community submitted a petition with 20,000 signatures to the Interim Land Council of the Governorate of Estland (Estonian Maanoukogu), calling for the Petseri County to be reunited with the Autonomous Governorate of Estonia. It was demanded that the districts inhabited mainly by the Setos be incorporated in Estonia, i.e. that the border be moved to the line from Siksälä in the district of Misso, south of the route between Pskov and Riga, to the settlement of Irboski (Russian Izborsk) and from there along a straight line to Lake Pskovskoye (Estonian Pihkva järv) ${ }^{19}$.

${ }^{15}$ Всероссийское совещание Советов рабочих и солдатских депутатов 29 марта 3 апреля 1917 г. в Петрограде. Стенограбический отчёт, ред. Михаил П. ЦАПЕнко, Москва-Ленинград 1927 [Vserossiyskoye soveshchaniye Sovetov rabochikh i soldatskikh deputatov 29 marta - 3 aprelya 1917 g. w Petrograde. Stenograficheskiy otchët, red. Michail N. CAPIENKo, Moskva-Leningrad 1927], pp. 290-296; Борьба за советскую власть в Прибалтике, ред. Исаак И. Минц [и другие], Москва 1967 [Bor'ba za sovetskuyu vlast'v Pribaltikie, red. Izaak I. Minc [et al.], Moskva 1967], pp. 65-72.

${ }^{16}$ A. Ju. BaKhturina, op.cit., pp. 180-182.

${ }^{17}$ Piotr Eberhardt, Problematyka narodowościowa Estonii (Zeszyty Instytutu Geografii i Przestrzennego Zagospodarowania PAN, z. 47), Warszawa 1997, p. 6.

${ }^{18}$ A. Ju. BAKHTURINA, op.cit., p. 184.

${ }^{19}$ Николай М. Миеневич, Российско-эстонская граница. История формирования и современное значение для развития Северо-Запада России, Псковский регионологиеский журнал, 2007, № 4 [Nikołaj M. MiEŻEWICZ, Rossiysko-estonskaya granitsa. Istoriya formirovaniya $i$ sovremennoye znacheniye dlya razvitiya Severo-Zapada Rossii, Pskovskiy regionologiyeskiy zhurnal, 2007, no. 4], p. 139. 
The Congress of Northwestern Oblast Councils, which took place on $23 \mathrm{July}^{20}$, decided to delineate the Governorate of Estland as a separate national territory, which had little in common with Pskov, the capital of the Oblast, either ethnically or economically. Therefore, a need for a separate organisational structure for Estonian councils - the Executive Committee of the Estonian Councils (Estonian Iskomest) - was acknowledged ${ }^{21}$. In October, the Interim Parliament (Estonian Maapäev) formed a government, which, however, did not manage to thrive. Soon, at the end of October, the Bolsheviks, who had support from the revolted troops of the Russian army that stationed in Estonian territory, forced the takeover of power. Initially in Tallinn and then in Tartu (German Dorpat, Russian Yuriev), Narva and all of south-eastern Estonia. In the capital, the Military Revolutionary Committee was established, which dominated the local Council of Delegates for Workers, Soldiers, the Landless and Smallholders of Estland.

On 15 (28) November 1917, the Interim Land Council of the Governorate of Estonia, that had been operating practically in the underground since the creation of the Military Revolutionary Committee ${ }^{22}$, announced in Tallinn that it was taking over supreme authority. It called for elections to be held for the Estonian Constituent Assembly to determine the political system of Estonia, which was to be independent of Russia ever since. In response, on 19 November (2 December) 1917, the Executive Committee of the Council of Delegates decided to dissolve the Interim Land Council, while maintaining the postulate to establish the Estonian Constituent Assembly and appointing elections to it for 21 January (3 February) 1918.

Earlier, on 10 (23) December 1917, a referendum was held in Narva and Jaanilinn on their affiliation to the Governorate of Estonia or the Governorate of Lifland ${ }^{23}$. More than $80 \%$ of the population voted in favour of Estonian affiliation. In connection with the outcome of the referendum, works on drafting the relevant legal act began, but they were soon interrupted ${ }^{24}$.

Unexpectedly, the Bolsheviks acknowledged the result of an earlier referendum held in Petseri (among the Seto people) and on 21 December 1917

${ }^{20}$ Formed in March 1917 from the governorates that had previously been part of the Northwestern Krai of the Russian Empire.

${ }^{21}$ Борьба за советскую власть в Прибалтике, рр. 87-89.

22 J. LeWANDOWSKI, Estonia, pp. 59-60.

${ }^{23}$ In the case of Narva, this was the second referendum. The first one, held on 2 June 1917, showed that the population decisively opted for joining Estonia, but its legitimacy was undermined. Н. М. Миеневич, op.cit., p. 139. The city was of great strategic, but also economic importance. It was one of the most important centres of the textile industry; it housed the largest and most modern cotton factories in the entire Russian Empire.

${ }^{24}$ Edgar Mattisen, Esti-Vene piir, Tallinn 1993, pp. 25-26. 
(3 January 1918) announced the decision to exclude the region from the territory of the Russian Soviet Federative Socialist Republic (RSFSR) ${ }^{25}$. Probably, as in the case of Finland, the leadership of the Russian Communist Party (Bolsheviks) was convinced that both countries (nations), Latvia and Estonia, were on the eve of the communist (Bolshevik) coup and such a gesture might strengthen its chances ${ }^{26}$. The winning 'class-conscious proletariat' of Estonia will certainly not act to separate itself from Bolshevik Russia, but to seek unity with it. This was confirmed by a joint meeting of the Estland and Tallinn committees of the Bolshevik party, which spoke out in favour of Estonia's entry into the RSFSR as an autonomous republic ${ }^{27}$.

Elections to the Estonian Constituent Assembly were held in January 1918, as planned. Although the highest percentage of votes was won by the Bolsheviks (37\%), they did not obtain a majority. As a result, the opening of the Constituent Assembly, scheduled for mid-February 1918, did not take place, as the Estonian Bolsheviks, like in Russia, unleashed terror by force, eliminating political opponents. As the offensive of German troops started towards the east, it also involved Estonian territories for a short time.

This was a result of the unsuccessful truce negotiations between the Bolsheviks and representatives of the Central Powers, which began in Brest on 9 (22) December 1917. The tactics of 'neither war nor peace' adopted by the chairman of the RSFSR delegation, Leon Trotsky, led to a crisis. After the RSFSR delegation refused to accept the German ultimatum on territorial demands, the parties abandoned the negotiations, and on 5 (18) February, the Ober-Ost troops ${ }^{28}$ resumed their offensive and attacked the Estonian territories from the West Estonian Archipelago and from the Latvian territories. On 11 (24) February, they occupied Pärnu, and on the following day, Tallinn and Petseri County, reaching as far as Pskov. By 18 February (3 March), they took control of the entire territory of the Governorate of Estonia and the northern part of the Governorate of Lifland inhabited by the Estonians ${ }^{29}$.

Having obtained information about German troops approaching Tallinn, Bolshevik troops left the capital, taking positions in the eastern and south-eastern

${ }^{25}$ Indrek JäÄTs, East Narva and Petserimaa, [in:] Contested Territory: Broder Disputes at the Edge of the Former Soviet Empire, ed. Tuomas ForsBerg, Aldershot 1995, p. 190.

${ }^{26}$ Документы внешней политики СССР, Т. 1: 7 ноября 1917 г. - декабря 1918 г., Москва 1957 [Dokumenty vneshney politiki SSSR, t. 1: 7 noyabrya 1917g. - 31 dekabrya 1918g., Moskva 1957], doc. 39, p. 71. Cf. W. MAteRski, Od „eksportu rewolucji” do „finlandyzacji”, p. 17.

${ }^{27}$ Борьба за советскую власть в Прибалтике, р. 150; С. А. КочегАРОв, Военно-политические аспекты становления независимого эстонского госудаства, р. 15.

${ }^{28}$ Ober Ost stands for the Supreme Command of All German Forces in the East (German Oberbefehlshaber der gesamten Deutschen Streitkräfte im Osten).

${ }^{29}$ Jan Lewandowski, Historia Estonii, Wrocław 2002, p. 171. 
[715] The Problem of the Demarcation of the Border between Estonia and Russia...

regions of Estonia ${ }^{30}$. This prompted Estonian nationalists, which were concentrated around the most recognisable Estonian politicians: the founder of the Estonian Democratic Party, Jaan Tõnnison, editor-in-chief of the Tallinn Gazette (Estonian Tallinna Teataja) Konstantin Päts and the former Interim Government Commissar, Jaan Poska, to demonstrate their own political position by entering into an anti-Soviet cooperation with Germany ${ }^{31}$. On 10 (23) February 1918 in Pärnu and on 11 (24) February in Tallinn, the Estonian Salvation Committee (Estonian Estimaa Pä̈̈stekomitee alias Pä̈̈stekomitee), newly created by the reinstated Land Council, announced the creation of an independent Estonian state (Estonian Esimene Eesti Vabariik) ${ }^{32}$.

The Estonian Declaration of Independence issued by the Committee, also known as the Manifesto to the Peoples of Estonia, stated: 'An unprecedented struggle of nations has destroyed the rotten foundations of the Russian Tsarist Empire'. Referring to the universally accepted principle of the self-determination of peoples, the Declaration proclaimed the creation of the Republic of Estonia, guaranteeing equal rights for all its inhabitants, regardless of their nationality, political and religious views, as well as cultural autonomy for Russian, German, Jewish and other national minorities. The most important part of the declaration, from the point of view of the issues under discussion, was that the following were incorporated within the borders of the independent Republic of Estonia: Harju County, Lääne County, Järva County, Virumaa, Viljandi County and Pärnu County, together with the Baltic Sea islands: Saaremaa, Hiiumaa, Muhu and other islands inhabited by the Estonian population. According to the Declaration, the final determination of the Republic's borders with Latvia and Russia was to be made by popular vote, after the end of the Great War ${ }^{33}$.

On 11 (24) February, the Interim Government of the Republic of Estonia was appointed with Päts as Prime Minister. However, the very next day, immediately after the Ober Ost troops entered Tallinn, the Germans interned the

\footnotetext{
${ }^{30}$ Some publications refer to the joint, victorious attack on Tallinn by the German army and the Estonian assault troops led by Johan Pitka.

${ }^{31}$ Tomasz Paluszyński, Walka o niepodległość Estonii, Łotwy i Polski. Porównanie, [in:] Polska $i$ kraje bałtyckie. Wybrane problemy $z$ dziejów Polski i krajów battyckich $w$ XX w., red. Arkadiusz Adamczyk, Dariusz Rogut, Piotrków Trybunalski 2011, p. 22.

${ }^{32}$ The text of the Manifesto to the Peoples of Estonia is available online: https://www.president .ee/en/republic-of-estonia/declaration-of-independence/index.html [accessed online 18 April 2018]. Since 1989, 24 February has been celebrated as a public holiday in Estonia - the Independence Day.

${ }^{33}$ Манифест ко всем народам Эстонии, Радуга, 1990, № 2 [Manifiest ko vsem narodam Estonii, Raduga, 1990, no. 2], p. 1. Сf. Аго Паюр, Рождение манифеста о независимости Эстонии, Тарту-Таллинн 2006 [Ago PAyUR, Rozhdeniye manifesta o nezavisimosti Estonii, Tartu-Tallinn 2006], p. 107; J. LeWANDOWsKi, Historia Estonii, pp. 193-194.
} 
Prime Minister and most of the ministers by introducing a military occupation administration. They dissolved the Estonian troops and also eliminated all the national institutions apart from the Estonian police, which they put under close supervision ${ }^{34}$. Nevertheless, these events played an important role in the process of uniting Estonians around the idea of a nation state, creating a new symbolic space.

On 3 March 1918, both sides, the Germans and the Bolsheviks, who were claiming control of Estonian territory, signed the Treaty of Brest, which meant Russia's withdrawal from the Great War. The course of the border through the Estonian territories, as marked by the Treaty, was to run along the Narva River, thus leaving out the territories inhabited by the Seto people on its eastern bank to the side of Bolshevik Russia, and the remainder of the Estonian territories, with the Petseri County south of Lake Peipus to the German side ${ }^{35}$. The Estonian delegation, consisting of the former members of the cabinet banned by the Germans, to the Entente Powers protested against the provisions of the Treaty of Brest, receiving the support of the Polish National Committee in Paris ${ }^{36}$.

According to the above-mentioned Declaration, referenda were to be held in the disputed border territories of Estonia with Latvia and Russia with regard to the nationality of their inhabitants. In the case of Latvia, with the participation of British observers ${ }^{37}$. After the Treaty of Brest, the dispute over the nationality of these territories seemed pointless. However, the Soviets started questioning the permanence of this demarcation only a few weeks later. By decision of the Bolshevik headquarters in April 1918, eight Russian north-western governorates (Arkhangelsk, Cherepovets, Novgorod, Olonets, Petrograd, Pskov, Severodvinsk and Vologda) were merged into the Union of Northern Oblast Communes ${ }^{38}$. The Union announced that it would aim to annex the lands lost to the Estonian bourgeoisie.

${ }^{34}$ С. А. КочеГАРОВ, Военно-политические аспекты становления независимого эстонского госудаства, p. 16; T. PALuszyńsкi, Walka o niepodległość Estonii, Łotwy i Polski, pp. 23-24.

${ }^{35}$ Traktat pokojowy pomiędzy Rosją a Niemcami, Austro-Węgrami, Bułgaria i Turcją, [in:] Prawo międzynarodowe i historia dyplomatyczna. Wybór dokumentów, t. 2, opr. Ludwik GELBERG, Warszawa 1958, doc. 10, pp. 15-16.

${ }^{36}$ Komitet Narodowy Polski. Protokoły posiedzeń 1917-1919, opr. Marek JABŁonowsKi, Dorota Cisowska-Hydzik (O Niepodległą i Granice, t. 6), Warszawa-Pułtusk 2007, p. 473.

${ }^{37}$ On the dispute on borders between Estonia and Latvia, see Tomasz Paluszyński, Konflikty graniczne pomiędzy państwami bałtyckimi: Litwą, Łotwa i Estonia w dobie ich walki o niepodległość w latach 1919-1921, Studia z Dziejów Rosji i Europy Środkowo-Wschodniej, t. 30: 1995, pp. 37-45.

${ }^{38}$ Between 1917 and 1919, the territories controlled by the Red Army were temporarily divided into four oblasts, which were administrative units of a higher level consisting of governorates: Moscow Oblast (1917-1918), Northern Oblast (1918-1919), Ural Oblast (1917-1919) and Western Oblast (1917-1918). 
Meanwhile, in the territories of Latvia and Estonia, controlled by the Ober-Ost troops, the self-government established by the local Germans (United Council of Lifland, Estland, the City of Riga and the Island of Saaremaa) proclaimed the creation of the Baltic Duchy (German Baltisches Herzogtum) on 12 April 1918. Such a solution to the problem of civilian administration of these areas was in line with the German government's concept of creating a German state on the eastern Baltic Sea (German Baltenland), referring to medieval traditions and based on the local German landowners ${ }^{39}$.

The notification of the establishment of the Baltic Duchy was protested by Soviet Russia (on 24 and 26 April), which - reserving that it respected the principle of self-determination of nations ${ }^{40}$ - questioned the treatment of the selfgovernment of the Baltic Germans as the representation of the entire Latvian and Estonian community. Moreover, it was pointed out that similar decisions should be agreed in advance between Germany and the RSFSR ${ }^{41}$. This protest probably slowed down the creation of the United Baltic Duchy (German Vereinigtes Baltisches Herzogtum $)^{42}$, which Berlin officially recognised on 22 September 1918, and the German military administration handed over power to its civil institutions in October. This was undoubtedly a manifestation of the policy towards the region by the new Chancellor Maximilian von Baden, who sought to establish quasi-independent local delegations in the Baltic region, separate for Estonia and Latvia, with a significant participation of local Germans $^{43}$. On 5 November, Adolf Friedrich zu Mecklenburg-Schwerin became the de jure ruler of the United Baltic Duchy, but de facto, he did not manage to take over the rule ${ }^{44}$.

The signing of the Armistice of Compiègne on 11 November and the outbreak of the revolution in Germany (9 November), which focused the authorities' attention almost exclusively on internal affairs, marked the end of German occupation of Estonian territory. On the eve of the Armistice of Compiègne, 10 November, the commander of the occupation authorities, General Adolf von Seckendorff, agreed to reactivate the Interim Government of Prime Minister Päts, although he did not formally hand over power to him until 7 December 1918, for fear of the Bolshevisation of Estonia. After the reconstruction

${ }^{39}$ T. PaluszyŃski, Walka o niepodległość Estonii, Łotwy i Polski, pp. 23-24.

${ }^{40}$ Cf. Wojciech Materski, Przewrót listopadowy 1917 r. w Rosji a hasło bolszewików prawa narodów do samostanowienia, Dzieje Najnowsze, R. 49: 2017, nr 4, pp. 7-28.

${ }^{41}$ Документы внешней политики СССР, Т. 1, doc. 199, pp. 321-323.

${ }^{42}$ Combining the Baltic Duchy and the miniature Duchy of Courland and Semigallia (German Herzogtum Kurland und Semgallen), created immediately after the signing of the Treaty of Brest in south-western Latvia.

${ }^{43}$ T. Paluszyński, Walka o niepodległość Estonii, Łotwy i Polski, pp. 24-25.

${ }^{44}$ For more, see John Hiden, The Baltic States and Weimar Ostpolitik, Cambridge 2002. 
carried out by the Prime Minister, the cabinet began to rebuild the state administration ${ }^{45}$. However, the withdrawal of German troops was soon halted, as the Entente Powers accepted the idea of leaving them to protect Estonia and Latvia against the Bolsheviks in addition to the so-called Baltic Landwehr (German Baltische Landeswehr) organised specially for this purpose. Over time, this was to lead to a serious conflict with Estonia and Latvia.

Having learnt about the signing of the Armistice of Compiègne, the AllRussian Central Executive Committee adopted a resolution to revoke the Treaty of Brest. The Executive Committee stated that it also liberated the Estonian people from the 'slavery to German imperialism' and invited them to a fraternal union with the workers and farmers of Russia, offering help and support in the fight to establish socialist power in their territories ${ }^{46}$. The consequence was the offensive of Bolshevik troops on Narva on 22 November 1918. After a week-long of heavy fighting, in which the attackers were resisted by combined Estonian-German forces, the city was captured. On 29 November the creation of the Commune of the Working People of Estonia (Estonian Eesti Töörahva Kommuun) - 'the government of the independent state of the Estonian workers' - was proclaimed with communist Jaan Anvelt as its leader. On 7 December, Moscow rushed to 'recognise the independence of the Soviet Republic of Estland', committing itself to showing its government and the army all the cooperation in their fight to free Estonia from the bourgeoisie ${ }^{47}$. Interestingly, the issue of borders was completely left out of the recognition decree, since, unlike Latvia, the Commune was supposed to administratively remain part of Russia despite its declared 'independence ${ }^{48}$.

The Commune of the Working People of Estonia, in accordance with the scheme used by Bolsheviks ${ }^{49}$, asked Moscow for 'fraternal help' to extend its power to the entire country. At the turn 1919, the Red Army occupied most of the Estonian territory, including the important centre of Tartu, although it did not manage to conquer Tallinn, which was crucial for the revolution success. It seemed that extending the Bolshevik Revolution to Estonia was a matter

${ }^{45}$ С. А. КочеГАРов, Военно-политические аспекты становления независимого эстонского госудаства, pp. 16-17; J. LewANDOWsкi, Historia Estonii, pp. 173-174.

46 Документы внешней политики СССР, Т. 1, doc. 398, pp. 565-567.

${ }^{47}$ For the facsimile of the original decree on recognizing the Commune of the Working People of Estonia, see Борьба за советскую власть в Прибалтике, pp. 222-223 (the facsimile inserted between the pages).

${ }^{48}$ Н. М. МиЕНевич, ор.cit., p. 139.

${ }^{49}$ Węzet polsko-białoruski 1918-1921. Dokumenty i materiały, opr. Wojciech MatersKi, Uadzimir SNApкоuski, Warszawa 2018, doc. 49, pp. 117-120; Борьба за победу советской власти в Грузии. Сборник документов и материялов (1917-1921 г.2.), Тбилиси 1958 [Bor'ba za pobedu sovetskoy vlasti v Gruzii. Sbornik dokumentov i materyalov (1917-1921 gg.), Tbilisi 1958], p. 659. 
of a few weeks at most ${ }^{50}$. The leadership of the Bolsheviks decided that the process of the Sovietisation of Estonia was a foregone conclusion, and most of the Red Army forces were withdrawn to defend Petrograd, which was threatened by the offensive of General Nikolai Yudenich's Northwestern Army of the Whites, supported by the United Kingdom ${ }^{51}$.

Taking advantage of this situation, the Estonian troops, led by General Johan Laidoner, which were equipped mainly by the British and reinforced by the units of the Northwestern Army and numerous volunteers, launched a counter-attack. Supported by the Royal Navy and British military aviation, they gained a lasting strategic initiative. After the victorious battles of Narva, Paju and Krivasoo, they drove out the Red Army troops from the entire territory of the country until the end of January, and advanced into the Latvian territory.

Under the new circumstances, from 5 to 7 April 1919, the elections to the Estonian Constituent Assembly were held again ${ }^{52}$. They were won by centreleft parties. On 9 May 1919 the Interim Government was dissolved and a new government of the Republic of Estonia, headed by Prime Minister Otto Strandman, was appointed for the first time in a fully democratic manner ${ }^{53}$.

At that time, the so-called first offensive of General Yudenich's troops on Petrograd was launched from Estonia. It was supported to a limited extent by the Estonian army. The Estonian army conquered the eastern areas inhabited by the Seto people, reaching Pskov, which it conquered at the end of May and maintained until the end of August ${ }^{54}$. The Estonian army also gave substantial assistance to the Latvian army in its fight against the troops of the aforementioned

${ }^{50}$ The Commune authorities in the territory of the Republic of Estonia controlled by the Red Army operated until February 1919, while the Commune itself was formally dissolved only in June that year. Cf. Борьба за советскую власть в Прибалтике, pp. 209-242.

${ }^{51}$ Герман А. Трукан, Антибольшевистские правительства России, Москва 2000 [Gierman A. Trukan, Antibol'shevistskiye pravitel'stva Rossii, Moskva 2000], p. 237. The conviction of the Bolshevik headquarters that the city was under serious threat lasted at least until June 1919. Cf. Włodzimierz LENIn, Projekt uchwaty KC RKP(b) w sprawie frontu Piotrogrodzkiego, [in:] idem, Dzieła wszystkie, t. 38: Marzec - czerwiec 1919, Warszawa 1988, p. 390.

${ }^{52}$ August Torma, Villibald Raud, Estonia 1918-1952, London 1952, pp. 6-7.

${ }^{53}$ Piotr Łossowski, Kraje bałtyckie na drodze od demokracji parlamentarnej do dyktatury (1918-1934), Wrocław 1972, pp. 12-16; Marcin SEPEŁOWsKI, Republika bez prezydenta-system konstytucyjny Republiki Estońskiej w świetle przepisów jej ustawy zasadniczej z 15 czerwca 1920 roku, Studia Iuridica Toruniensia, t. 14: 2014, pp. 321-322.

${ }^{54}$ They even tried to create the so-called Pskov Republic under the rule of General Stanislav Bulak-Balyakhovich in this territory, which was to act as a buffer zone separating Estonia from Russia. Cf. T. PAluszyński, Walka o niepodległość Estonii, Łotwy i Polski, p. 44; Oleg ŁatyszoneK, Spod czerwonej gwiazdy pod biały krzyż, Zeszyt Naukowy Muzeum Wojska, nr 6: 1992, pp. 43-45; Marek CABAnowski, Generał Stanisław Bułak-Bałachowicz. Zapomniany bohater, Warszawa 1993, pp. 17-19. 
Baltic Landwehr, which attempted to take control of Latvia ${ }^{55}$. In the fights that took place in June and July, Estonian troops reached the capital city of Riga, which contributed to a truce, and then the dissolution of the Landwehr and creation of a tactical group within the Latvian army based on the personnel of the Landwehr ${ }^{56}$.

On 4 June 1919, the Estonian Constituent Assembly adopted a temporary constitution, which also in part described the territory of the state, mentioning the Petseri County and the territories on the eastern bank of the Narva River as its integral parts ${ }^{57}$. This aroused a negative reaction from both the Bolsheviks and the Whites. However, in the manifesto of the Government of Northwest Russia of 11 August 1919, written under the influence of the British, there was a provision that stated the Government of Northwest Russia (a state including the former governorates of Petrograd, Pskov and Novgorod) recognised the total independence of Estonia ${ }^{58}$.

In the summer of 1919, on the initiative of Great Britain, an attempt was made to create an anti-Bolshevik alliance of the countries of north-eastern Europe, bringing together the Baltic republics, to be united as a single state reaching 'from Klaipeda to Reval and beyond, to St Petersburg', and Poland ${ }^{59}$. It was based on the conviction that Latvia and Estonia were 'temporary entities'

${ }^{55}$ Cf. Petris Radzinš, Wojna o niepodległość Łotwy, Polska Zbrojna, 1929, nr 101-105; Waldemar Rezmer, Małe państwa bałtyckie 1918-1940. Próby sojuszy wojskowych, [in:] Nad Bałtykiem. W kregu polityki, gospodarki, problemów narodowościowych i społecznych w XIX i XX wieku. Księga jubileuszowa poświęcona profesorowi Mieczysławowi Wojciechowskiemu, red. Zbigniew Karpus, Jarosław KŁaczkow, Mariusz WoŁos, Toruń 2005, pp. 932-933.

${ }^{56}$ On 23 June 1919, Estonian and Latvian troops won a significant victory at the Battle of Cēsis (Estonian Võnnu, German Wenden) in Latvia, which resulted in a ceasefire (2 July). Since 1934, this date has been a public holiday in Estonia - the Victory Day. Andres KaSeKamp, Historia państw bałtyckich, tł. Anna ŻukowsKa-Maziarska, Warszawa 2013, pp. 104-105; T. PALuszyŃski, Walka o niepodległość Estonii, Łotwy i Polski, pp. 38-39. For more, see Hannes Valter, Ausalt ja avameelselt Landeswehri sõjast. Võnnu lahingust. Riia operatsioonist, Tallinn 1989.

57 'Võrumaa ühes Narva linna ja ümbruskonnaga, Tartumaa ühes Piirisaarega, Petserimaa (Petseri linn ühes Petseri), Irboska (Isborski), Pankovitsa ja Labotka (Slobotka) vallaga'; see the official journal of the Republic of Estonia: Riigi Teataja, 1919, no. 44. See also I. JÄÄTs, op.cit., p. 191.

${ }^{58}$ As cited in Серге́й А. Воронов, Петроград-Вятка в 1919-20 2.2., [in:] Архив Русской Революичи, Т. 1, ред. Иосиф В. Гессен, Москва 1991 [Siergiej A. Woronow, Petrograd-Vatka v 1919-20 gg., [in:] Arkhiv Russkoy Revolyutsii, t. 1, red. Iosif W. Gessen, Moskva 1991], p. 241. The Government of Northwest Russia formed on 10 August 1919 in Reval (Tallinn) by Cadets, Social Revolutionaries and Mensheviks, with General Nikolai Yudenich as the Minister of War. It was dissolved on 5 December 1919, during the retreat of the troops, after the unsuccessful attack on Petrograd.

${ }^{59}$ Michał Römer, Dzienniki, t. 3: 1916-1919, opr. Grzegorz Nowik, Warszawa 2018, p. 760. See also Eugeniusz Romer, Pamiętnik paryski (1918-1919), opr. Andrzej Garlicki, Ryszard ŚwięTeK, Wrocław 1989, p. 299. 
that would not be able to survive on their own ${ }^{60}$. Negotiations held on this issue in Riga at the end of August led to agreeing on a formal basis for military cooperation, which posed a real threat not only to Petrograd but to the Bolshevik regime in general.

In this situation, on 31 August, the Council of People's Commissars of the RSFSR addressed Estonia with a proposal to start peace negotiations 'with a view to establishing the border of the Estland state, as well as to establishing a buffer zone between Russian and Estonian troops, agreeing on forms of control over the settlements included in this zone ${ }^{61}$. The note included a clear announcement that the independence of the 'Estland state' would be recognised, but it was drafted in offensive terms. It used the term 'the government of Reval' to address the authorities of the Republic of Estonia, accused them of being guided solely by the interests of the Entente Powers, and made the peace talks conditional on the withdrawal of the Estonian authorities from all military operations against Soviet Russia.

Ten days later, the head of the People's Commissariat for Foreign Affairs, Georgy Chicherin, made a similar proposal to the other Baltic republics ${ }^{62}$. The meaning of all these offers was obvious. It was, first and foremost, a tactical move. Chicherin aimed at depriving the Whites of support from the armies of the Baltic republics in the Russian Civil War. They were not very numerous, but as the May offensive on Petrograd (Pskov) showed, quite valiant. Also in the future, under the conditions of the planned march on Europe, 'export of the Revolution' to Poland, Germany and further on to the continent, the neutralisation of the Baltic republics, involving them in peace negotiations, would undoubtedly increase the security of the northern wing of the Red Army, which was heading for the west.

Contrary to pressure from the Entente Powers, to the dissatisfaction of the Latvians $^{63}$, and notwithstanding the obvious facts of armed interference by the Bolsheviks in the internal affairs of the Republic ${ }^{64}$, the Estonian authorities

${ }^{60}$ Maciej RataJ, Pamiętniki. 1918-1927, opr. Jan Dęвsкi, Warszawa 1965, p. 209.

${ }^{61}$ Документы внешней политики СССР, Т. 2: 1 января г. - 30 июня 1920 г., Москва 1958 [Dokumenty vneshney politiki SSSR, t. 2: 1 yanvarya $1919 \mathrm{~g}$. - 30 iyunya $1920 \mathrm{~g}$., Moskva 1958], doc. 156 , p. 242.

${ }^{62}$ Ibid., doc. 161, pp. 246-247; ibid., doc. 164, pp. 250-252; История внешней политики СССР, Т. 1: 1917-1945 г2., Москва 1976 [Istorya vneshney politiki SSSR, t. 1: 1917-1945 gg., Moskva 1976], p. 110.

${ }^{63}$ Part of eastern Latvian territory (Latgale) was still occupied by Bolshevik troops and Tallinn's acceptance of the Soviet offer of negotiations was treated by Riga as a betrayal of the independence of the Baltic republics. Cf. Piotr Łossowski, Stosunki polsko-estońskie 1918-1939, Gdańsk 1992, pp. 14-15.

${ }^{64}$ Документы внешней политики СССР, Т. 2, doc. 157, р. 243. 
decided to accept the offer. They controlled all Estonian lands, and in a society tired of prolonged war, anti-war sentiments intensified, also among soldiers. This decision was probably also influenced by rumours that after the capture of Petrograd, General Yudenich's next objective would be Tallinn, and the elimination of the 'self-proclaimed' governments of Estonia and Latvia ${ }^{65}$.

Talks were inaugurated on 17 September in Pskov, a city located near the border. The Soviet delegation arrived there under the leadership of a relatively low-rank politician, an official of the People's Commissariat for Foreign Affairs, Maxim Litvinov. The Estonian delegation was led by Deputy Speaker of Parliament, and soon-to-be Minister of Foreign Affairs, Ado Birk. The conference plunged into a crisis situation right at the inaugural meeting in connection with the statement by the head of the Estonian delegation. He said that the authorities of the Republic of Estonia would accept any offer of peace, including from the Bolsheviks, because peace and stability was their primary objective. Therefore, Estonia was ready to hold peace talks with the Bolsheviks, provided that it is confirmed that similar peace talks were taking place between them and the other Baltic republics. Without this condition fulfilled, Estonia could not withdraw from the war without harming the defences of its neighbours ${ }^{66}$.

In view of this condition, Litvinov stated that Moscow had made an offer of truce negotiations to the other Baltic republics that was similar to the one given to Tallinn and expected a response from them. At the same time, he accused the Estonian delegation of boycotting the talks by imposing conditions that indicated a lack of willingness to reach agreement, which meant the actual violation of the truce. At Birk's request, the meeting was suspended so that the Estonian delegation could contact the authorities in Tallinn. The following day, without resuming the proceedings, the talks were discontinued ${ }^{67}$. The delegations retired.

Shortly afterwards, on 4 October 1919, Jaan Poska, the Minister of Foreign Affairs of the Republic of Estonia, addressed the People's Commissariat for Foreign Affairs of the RSFSR, with a note on the readiness of the governments of Estonia and the other Baltic republics to enter into peace negotiations, not later than by 25 October 1919. In the correspondence that followed, Poska specified the place and purpose of the meeting. He proposed that the talks should take place in Tartu and that their preliminary phase should be devoted to making sure that the Bolsheviks would show their unconditional respect for the right to self-determination of peoples, and the entailing recognition of

${ }^{65}$ T. Paluszyński, Walka o niepodległość Estonii, Łotwy i Polski, p. 42.

${ }^{66}$ Документы внешней политики СССР, Т. 2, p. 744, note 50.

${ }^{67}$ Ibid., doc. 162 , pp. 247-248. The reason for this was probably the information about the offensive on Moscow launched by General Anton Denikin. 
the independence of the Baltic republics and the designation of a buffer zone between them and Russia ${ }^{68}$.

However, due to Latvia's renewed involvement in the war with the troops of General Pavel Bermondt-Avalov's West Russian Volunteer Army and General Rüdiger von der Goltz's German $6^{\text {th }}$ Reserve Corps $^{69}$, talks did not take place on schedule. Nevertheless, the Estonian authorities prolonged their readiness for the talks on a bilateral basis ${ }^{70}$. The implementation of this readiness was delayed, because the authorities in Tallinn were clearly awaiting the developments on the front line of the so-called second offensive of General Yudenich's Northwestern Army to Petrograd ${ }^{71}$, which began in September, and in particular the march of General Anton Denikin's army to Moscow ${ }^{72}$.

At the end of November, however, the situation of the Bolsheviks in the north-western region improved radically. The offensive of General Yudenich's army failed on the outskirts of Petrograd, $20 \mathrm{~km}$ from the city. The counterattack of the Red Army forced it to retreat towards Estonia. On the Estonian border, General Yudenich and the Estonian army managed to hold the front line, after which - theoretically - his troops were interned in the Republic ${ }^{73}$. In the battles that lasted until the end of December, the Estonian army not only defended its national territory, but also occupied adjacent areas in the east, partly inhabited by Finno-Ugric people. No further clashes took place, because soon the entire effort of the Bolsheviks focused on other military theatres of the Russian Civil War.

The Estonian-Bolshevik peace negotiations were resumed on 5 December $1919^{74}$. At the first meeting, the Soviet delegation was temporarily led by Leonid Krasin, the head of the People's Commissariat for Communications,

\footnotetext{
${ }^{68}$ Ibid., post linea doc. 167, pp. 255-256. Another condition was to ban Bolshevik propaganda in the Baltic republics.

${ }^{69}$ Recruited from February 1919 on the basis of the former Baltic Landwehr, the former German 'Iron Division', the former Russian Volunteer Corps of Prince Lieven and various White Guard units.

${ }^{70}$ Ibid., p. 256.

${ }^{71}$ In which Estonian troops took a limited part by, for example, occupying Yamburg (Estonian Jaama) and contributing to the occupation of Pskov.

${ }^{72}$ The Armed Forces of South Russia under the leadership of General Denikin, after occupying Kursk and Voronezh at the end of September, occupied Oryol in mid-October and were preparing to strike directly at Moscow. С. Антон И. Деникин, Путь русского офицера, ред. Елена В. ТолкачевА, Москва 2003 [Anton I. Deniкin, Put' russkogo ofitsera, red. Yelena V. Tolkacheva, Moskva 2003], pp. 508-516.

${ }^{73}$ In anticipation of the Bolsheviks' possible defeat in the Russian Civil War, the Estonian authorities, not wanting to spoil the relations with the Whites, did not decide to disarm them until the end of 1919.

${ }^{74}$ Известия [Izwiestija], 10 December 1919, no. 274 (826); Документы внешней политики СССР, Т. 2, doc. 195, pp. 299-304.
} 
who only came to their inauguration. At subsequent meetings, it was chaired by a specialist in difficult diplomatic negotiations, Adolph Joffe. This time the proceedings were more efficient, and both delegations clearly seemed interested in their success ${ }^{75}$.

A substantive discussion on the issue of demarcation began with an address by the chairman of the Estonian delegation Poska at the meeting on 8 December $^{76}$. He demanded that ethnic-historical arguments be taken as a basis for demarcation, which would prove Estonia's rights to the regions of Narva/Jaanilinn and Petseri. In response to these demands, Joffe estimated that they would involve the loss of approximately $10,000 \mathrm{~km}^{2}$ of historically Russian land. He put forward what he described as a compromise, with the border running along the Narva River, so that part of the twin city of Narva-Ivangorod and the islands on the river would remain on the Russian side. However, he completely ignored the question of the Petseri County, which had never been part of Estonia. He called on the Estonian side to take into account not only its historical and ethnic arguments, but also Russia's military and strategic interests, which Moscow could not ignore.

Poska described this 'compromise' as favouring annexation of Estonian territories into Russia. However, he promised that the Estonian delegation would consider it and present its opinion at the next meeting. As one might have expected, the proposal was not accepted, and instead a revised draft demarcation from Poska's original proposal was put forward. The situation did not seem to offer any possibility of compromise, but after several meetings an agreement was achieved. It was considered acceptable to draw a demarcation line along the line of the military front which at that time ran along the Komarovka River in the north, $7 \mathrm{~km}$ east of Narva (within the range of artillery fire from Narva). On this basis, on the last day of the year truce preliminaries were signed ${ }^{77}$. This happened on the eve of the Polish-Latvian offensive in the area of Daugavpils (Dinaburg), called 'Operation Winter', aimed at liberating all of Latgale from the Soviet occupation.

Speaking publicly on 24 January 1920, the head of the Soviet Party, Vladimir Lenin, made a statement in response to the criticism of this compromise, which was widespread in the RSFSR: 'We have made a number of concessions,

${ }^{75}$ The Estonian delegation included: Jaan Poska, Ants Piip, Mait Püüman, Julius Seljamaa and Jaan Soots. Whereas the Soviet delegation included: Leonid Krasin, Adolph Joffe and Isidore Gukovsky.

${ }^{76}$ For the course of negotiations, see E. Mattisen, Esti-Vene piir, pp. $63 \mathrm{ff} . ;$ H. M. МиeнEвич, ор.cit., pp. 140-141.

77 Документы внешней политики СССР, Т. 2, doc. 214, pp. 317-319. Cf. С. А. КочЕГАРОВ, Военно-политические аспекты становления независимого эстонского госудаства, pp. 21-22. 
the main one being the waiver of the disputed territory inhabited by a mixed Russian and Estonian population. However, we do not want the bloodshed of workers and Red Army soldiers over a piece of land, especially as this waiver is not eternal', because 'Estonian workers will soon overthrow the current authorities and create a Soviet Estonia that will make a new peace with us $^{78}$. It was not insignificant for him that the Bolsheviks got out of isolation, and that Estonia was persuaded to break the Entente Powers' policy of solidarity on this issue, as a consequence of which the Soviet Russia obtained 'a window on Europe' through Estonian territory ${ }^{79}$.

On 2 February 1920 the chairmen of both delegations, Poska and Joffe, signed a peace treaty ${ }^{80}$. In exchange for the recognition of Estonia's independence, despite not achieved through class struggle and revolution, the Bolsheviks obtained something that could compensate for the harm done to their image by negotiations with capitalists and what they considered most important at the time. Namely, securing Petrograd against a renewed offensive launched from the Estonian lands, important in terms of both their situation in the Russian Civil War, the Polish-Soviet War, and their plans to export the Revolution to the West ${ }^{81}$.

The second article of the peace treaty stated: 'Taking as the point of departure the right of all peoples to self-determination, proclaimed by the RSFSR, including the right to full separation from the state of which they were part, Russia recognises unconditionally the independence and sovereignty of the Estonian State and renounces, voluntarily and eternally, all sovereign rights which it enjoyed over Estonian territory and over its people due to the previously existing legal and political system and, at the same time, due to international treaties which, in the aspect indicated herein, lose their power for the future' 82 .

${ }^{78}$ Włodzimierz LENIN, Przemówienie na bezpartyjnej konferencji robotników i czerwonoarmistów w dzielnicy Presnia, [in:] idem, Dzieła wszystkie, t. 40: Grudzień 1919 - kwiecień 1920, Warszawa 1988, pp. 68-69.

${ }^{79}$ Which Lenin described as 'the most momentous event' when characterising the international situation, see Włodzimierz Lenin, Przemówienie na konferencji kolejarzy Moskiewskiego Węzła Kolejowego, [in:] idem, Dzieła wszystkie, t. 40: Grudzień 1919 - kwiecień 1920, Warszawa 1988, p. 107.

${ }^{80}$ For the Estonian text, see https://ida.aule.ee/juriidika/Tartu_rahuleping.pdf [accessed online 18 April 2018]. For the Russian text, seе Документы внешней политики СССР, Т. 2, doc. 229, pp. 339-352.

${ }^{81}$ Сергей А. КочегАров, Тартуский мирный договор и Белое движение на Северо-Заnaде Росси, Клио. Ежемесячный журнал для учёных, 2014, № 1 [Siergiej A. KoczEgAROw, Tartuskiy mirnyy dogovor i Beloye dvizheniye na Severo-Zapade Rossi, Klio. Yezhemesyachnyy zhurnal dlya uchënykh, 2014, no. 1], pp. 87-92; Mikołaj Mirowski, Rewolucja permanentna Lwa Trockiego. Między teoriq a praktyką, Warszawa 2013, pp. $142 \mathrm{ff}$.

${ }^{82}$ Документы внешней политики СССР, Т. 2, doc. 229, p. 340. 
As it is widely known, the 'eternity' came to an end in the summer of 1940. Estonia did not regain the demarcation line of 1920 either after the annexation, during the rule of the Soviet Union (as a Soviet republic) or after its dissolution (as the Republic of Estonia).

Translated by Tomasz Leszczuk

\section{BIBLIOGRAPHY}

Bakhturina, Aleksandra J. "Izmeneniye administrativnykh granits Pribaltiyskikh guberniy vesnoy-letom 1917 g." Vestnik Rossiyskogo Gumanitarnogo Gosudarstvennogo Universiteta. Politologiya. Istoriya. Mezhdunarodnyye otnosheniya 4/2 (2017): 177-185.

Brüggemann, Karsten. "Estoniya i Petrogradskiy front grazhdanskoy voyny 1918-1920 v gg." Voprosy istorii (2007) issue 5: 17-33.

Cabanowski, Marek. Generat Stanisław Bułak-Bałachowicz. Zapomniany bohater. Warszawa: P.W. „Mikromax”, 1993.

Cywiński, Bohdan. Szańce kultur. Szkice z dziejów narodów Europy Wschodniej. Warszawa: Wydawnictwo TRIO, 2013.

Eberhardt, Piotr. Problematyka narodowościowa Estonii. Warszawa: Instytut Geografii i Przestrzennego Zagospodarowania PAN, 1997.

Graf, Mati. Estoniya i Rossiya 1917-1991. Anatomiya rasstavaniya. Tallin: Kirjastus ARGO, 2007.

Hiden, John. The Baltic States and Weimar Ostpolitik. Cambridge: Cambridge University Press, 2002.

Jääts, Indrek. "East Narva and Petserimaa." In Contested Territory: Broder Disputes at the Edge of the Former Soviet Empire, edited by Tuomas Forsberg, 188-201. Aldershot: Edward Elgar Publishing Company, 1995.

Kasekamp, Andres. Historia państw battyckich. Translated by Anna Żukowska-Maziarska. Warszawa: Polski Instytut Spraw Międzynarodowych, 2013.

Koczegarow, Siergiej A. Voyenno-politicheskiye aspekty stanovleniya nezavisimogo estonskogo gosudarstva (1917-1920 gody). Sankt-Peterburg: Sankt-Peterbugskiy gosudarstvennyy universitet aerokosmicheskogo priborostroyeniya, 2018.

Koczegarow, Siergiej A. “Tartuskiy mirnyy dogovor i Beloye dvizheniye na Severo-Zapade Rossi." Klio. Yezhemesyachnyy zhurnal dlya uchënykh (2014) issue 1: 87-92.

Lewandowski, Jan. Estonia. Warszawa: Wydawnictwo TRIO, 2001.

Lewandowski, Jan. Historia Estonii. Wrocław: Zakład Narodowy im. Ossolińskich, 2002. Łatyszonek, Oleg. "Spod czerwonej gwiazdy pod biały krzyż." Zeszyt Naukowy Muzeum Wojska 6 (1992): 41-49.

Łossowski, Piotr. Kraje battyckie na drodze od demokracji parlamentarnej do dyktatury (1918-1934). Wrocław: Zakład Narodowy im. Ossolińskich, 1972.

Łossowski, Piotr. Stosunki polsko-estońskie 1918-1939. Gdańsk: Instytut Bałtycki, 1992. Materski, Wojciech. Od 'eksportu rewolucji' do 'finlandyzacji'. Sowiecko-finski spór terytorialny 1917-1991. Warszawa: Instytut Studiów Politycznych PAN, 2019. 
Materski, Wojciech. "Przewrót listopadowy 1917 r. w Rosji a hasło bolszewików prawa narodów do samostanowienia.” Dzieje Najnowsze 49/4 (2017): 7-28.

Mattisen, Edgar. Esti-Vene piir. Tallinn: Esti Rahvusülikool, 1993.

Mattisen, Edgar. Estoniya-Rossiya. Istoriya granitsy i yeyë problemy. Translated by Elkond Libman and Irina Nikitina. Tallinn: ILO, 1995.

Mieżewicz, Nikołaj M. "Rossiysko-estonskaya granitsa. Istoriya formirovaniya i sovremennoye znacheniye dlya razvitiya Severo-Zapada Rossii." Pskovskiy regionologiyeskiy zhurnal (2007) issue 4: 134-149.

Minc, Izaak I., Drizuł, Aleksandr A., Żugżda, Juozas I., and Maamiagi, Wiktor A., eds. Bor'ba za sovetskuyu vlast' v Pribaltike. Moskva: Akademiya Nauk SSSR, 1967.

Mirowski, Mikołaj. Rewolucja permanentna Lwa Trockiego. Między teoriq a praktyką. Warszawa: Wydawnictwo DiG, 2013.

Paluszyński, Tomasz. "Konflikty graniczne pomiędzy państwami bałtyckimi: Litwą, Łotwą i Estonią w dobie ich walki o niepodległość w latach 1919-1921.” Studia z Dziejów Rosji i Europy Środkowo-Wschodniej 30 (1995): 37-46.

Paluszyński, Tomasz. Walka o niepodległość Estonii 1914-1920. Poznań: Oficyna Wydawnicza Wyższej Szkoły Języków Obcych, 2007.

Paluszyński, Tomasz. "Walka o niepodległość Estonii, Łotwy i Polski. Porównanie." In Polska i kraje bałtyckie. Wybrane problemy z dziejów Polski i krajów bałtyckich $w X X w$., edited by Arkadiusz Adamczyk and Dariusz Rogut, 20-34. Piotrków Trybunalski: Naukowe Wydawnictwo Piotrkowskie, 2011.

Payur, Ago. Rozhdeniye manifesta o nezavisimosti Estonii. Tartu, Tallinn: Natsional'nyy Arkhiv, 2006.

Rataj, Maciej. Pamiętniki. 1918-1927. Edited by Jan Dębski. Warszawa: Ludowa Spółdzielnia Wydawnicza, 1965.

Rezmer, Waldemar. "Małe państwa bałtyckie 1918-1940. Próby sojuszy wojskowych." In Nad Bałtykiem. W kręgu polityki, gospodarki, problemów narodowościowych i społecznych w XIX i XX wieku. Księga jubileuszowa poświęcona profesorowi Mieczysławowi Wojciechowskiemu, edited by Zbigniew Karpus, Jarosław Kłaczkow and Mariusz Wołos, 931-941. Toruń: Wydawnictwo Uniwersytetu Mikołaja Kopernika, 2005.

Romer, Eugeniusz. Pamiętnik paryski (1918-1919). Edited by Andrzej Garlicki and Ryszard Świętek. Wrocław: Zakład Narodowy im. Ossolińskich, 1989.

Römer, Michał. Dzienniki, vol. 3: 1916-1919. Edited by Grzegorz Nowik. Warszawa: Ośrodek KARTA, 2018.

Sepełowski, Marcin. "Republika bez prezydenta - system konstytucyjny Republiki Estońskiej w świetle przepisów jej ustawy zasadniczej z 15 czerwca 1920 roku.” Studia Iuridica Toruniensia 14 (2014): 317-338.

Torma, August and Raud Villibald. Estonia 1918-1952. London: UCL School of Slavonic and East European Studies, 1952.

Trojnickij, Nikołaj A. and Władimir W. Nieudaczin, eds. Pervaya vseobshchaya perepis' naseleniya Rossiyskoy imperii. 1897, vol. 49: Estlandskaya guberniya. Sankt-Peterburg: Tsentral'nyy Statisticheskiy Komitet Ministerstva Vnutrennykh Del, 1905.

Trukan, Gierman A. Antibol'shevistskiye pravitel'stva Rossii. Moskva: Institut Rossiyskoy Istorii RAN, 2000. 
Valter, Hannes. Ausalt ja avameelselt Landeswehri sõjast. Võnnu lahingust. Riia operatsioonist. Tallinn: Perioodika, 1989.

Wilbrecht, Aleksandr M., ed. Rossiyskiy atlas iz soroka chetyrëkch kart sostoyahchiy i na sorok dva namestnichestva imperiyu razdelyayushchiy. Moskva: Gosudarstwiennyj Istoriczeskij Muzej, 2006.

Woronow, [S.]. "Petrograd-Vatka v 1919-20 gg." In Arkhiv Russkoy Revolyutsii, vol. 1, edited by Iosif W. Gessen, 251-256. Moskva: TERRA-Politizdat, 1991.

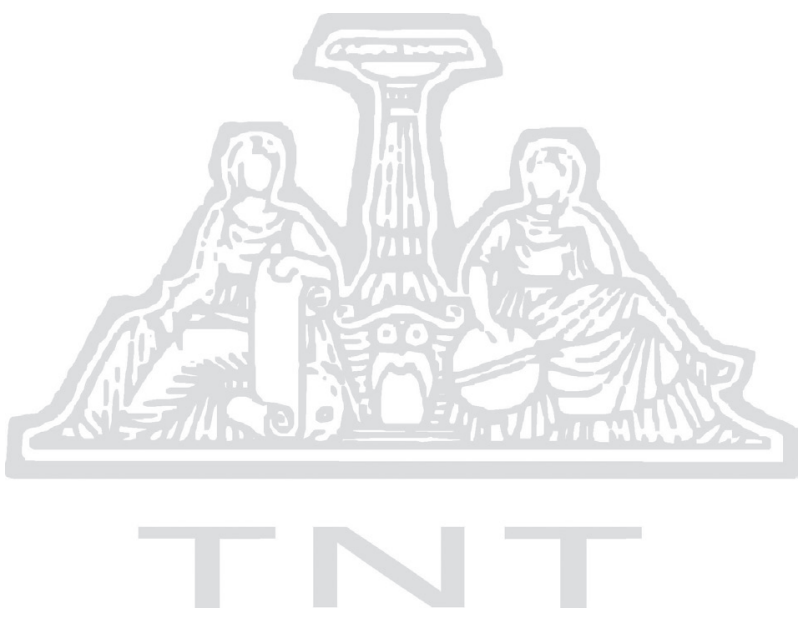

